\title{
PECULIARITIES OF LABORATORY SUPPORT FOR MASS INTERNATIONAL EVENTS
}

\author{
G.V. Karpushchenko ${ }^{1}$, A.V. Motskus ${ }^{2}$ \\ ${ }^{1}$ Center for Hygiene and Epidemiology in Rostov Region, 67, 7-ya liniya Str., Rostov-na-Donu, 344019, \\ Russian Federation \\ ${ }^{2}$ Rostov State Medical University, 29 Nakhichevanskiy lane, Rostov-na-Donu, 344022, Russian Federation
}

Any mass political, cultural, or sport event causes risks of complicated medical and sanitary situations and health disorders. It makes it necessary to perform profound preparations, both at all objects where such events take place and on overall territories of settlements where these objects are located. Orientation at risk minimization requires changes in existing schemes of state sanitary-epidemiologic surveillance and, accordingly, in providing efficient laboratory support. The article dwells on peculiarities of laboratory examinations during preparations to mass international events and events themselves. It also justifies the necessity to work out hygienic model of laboratory support for the said events.

The authors suggest to create laboratory support programs for sanitary-epidemiologic surveillance allowing for specific features of various stages in preparation to an event: 1) a stage when objects and infrastructure necessary for an event are planned and constructed; 2) a stage when an actual event takes place; 3) a stage after an event is over. The first stage involves concentration on control over materials and constructions applied when objects are erected. At the second stage it is necessary to provide strict control over environmental objects with wider application of express tests and mobile laboratory equipment. The third stage should involve systemic monitoring over loads on a territory caused by growth in number of tourists and the necessity to provide proper functioning of hygienically significant infrastructural systems.

The suggested approaches were tested during preparations to 2018 FIFA World Cup In Rostov-on-Don. A test laboratory center, supervised by Rospotrebnadzor regional office, used the latest laboratory equipment which allowed to perform a wide range of research on construction and finishing materials, as well as environmental objects. The equipment operated practically round-the-clock, and it is advisable to apply the accumulated potential in future.

The authors stress that it is vital to develop a hygienic model of laboratory control over mass international events.

Key words: a mass international event, risks minimization, laboratory research, stages of an event, hygienic model, laboratory support, systemic monitoring.

The growing credibility of Russian Federation predetermines further increase in the number of mass international events held on our territory. The World Health Organization stresses that "... in the course of a mass event, urgent, complex medical and sanitary situations may arise ... risks to human health may increase ..." [1]. This fact causes the need for a huge preparatory work, both on the sites themselves and in the territories of municipalities hosting the events. The above requires modification of the existing schemes of state sanitary and epidemiological surveillance and, accordingly, its effective laboratory support. This applies to events of very different levels and content - from political and cultural

(C) Karpushchenko G.V., Motskus A.V., 2018

Garri V. Karpushchenko - Candidate of Medical Sciences, Chief Physician (e-mail: master@donses.ru; tel.: +7 (863) 251-04-92).

Anna V. Motskus - an Assistant at Common Hygiene Department, Candidate of Medical Sciences (e-mail: okt@rostgmu.ru; tel.: +7 (863) 250-42-04). 
ones to sports, including sports of higher achievements [2].

Participants in sport events are most demanding for factors of the external environment. This is due to the intensification of physiological processes of athletes in the process of training and competitions [3, 4]. A number of sport events are held in natural conditions, but most large-scale sport events take place in cities, often large and densely populated, where the natural environment is aggravated by exposure to high levels of air, water and noise. At the same time, pollution of an external and indoors environment often affects negatively the health of competitors and sports results [58]. As a consequence, the task of quality control over the habitat of mass sports events participants and guests is becoming urgent, with its highest credibility achieved by laboratory research [9].

The peculiarities of laboratory studies aimed at determining epidemiological risks, as well as the radiation situation, have been widely and thoroughly studied in scientific works devoted to the mass international events in Russian Federation ${ }^{1}$ $[10,11]$. The research was carried out to support the organization of events such as World Universiade in Kazan, Winter Olympic Games in Sochi, and others.

Changes in the levels of exposure to hygienically significant factors affects all the stages of preparing and hosting mass international event and, the organization of laboratory support at different stages has certain features. Therefore, it is advisable to analyze such changes in the context of various stages of an international event, and namely: the preparatory, including facilities reconstruction and construction; holding itself of a large-scale international event; post-event period.

On the example of Rostov region, the features of laboratory control at various stages of preparation and holding of FIFA World Cup 2018 games are considered.

The provision of laboratory research during the preparation and holding of the World Cup games in Rostov Region is carried out in accordance with the "Procedure for laboratory support of environmental research during the preparation and holding of FIFA World Cup 2018 games in Rostov-on-Don" approved by Rospotrebnadzor

This procedure considers research in two areas:

- monitoring of environmental factors (water, air, soil, etc.) in a hosting territory, the relevance of which has been confirmed many times $[12,13]$;

- laboratory research on the involved facilities for living, catering, sports and training bases, life support facilities (studies of the construction materials, water from centralized systems, administrative premises, food, etc.) [14].

The approved procedure does not regulate clearly the conduct of laboratory research, depending on the stage of preparation and holding a massive international

\footnotetext{
${ }^{1} \mathrm{O}$ sostoyanii sanitarno-epidemiologicheskogo blagopoluchiya naseleniya Krasnodarskogo kraya v 2014 godu: Gosudarstvennyi doklad [On the state of sanitary and epidemiological welfare of the population of the Krasnodar Territory in 2014: State report]. Krasnodar, Upravlenie Rospotrebnadzora po Krasnodarskomu krayu, Publ., 2015, 212 p. (in Russian).

O sostoyanii sanitarno-epidemiologicheskogo blagopoluchiya naseleniya Respubliki Tatarstan v 2013 godu: Gosudarstvennyi doklad [On the state of sanitary and epidemiological welfare of the population of the Republic of Tatarstan in 2013: State report]. Kazan, Upravlenie Rospotrebnadzora po Respublike Tatarstan, Publ., 2014, 212 p. (in Russian)

${ }^{2} \mathrm{O}$ sanitarno-epidemiologicheskom blagopoluchii naseleniya: Federal'nyi zakon № 52-FZ ot 30.03.1999 g. [On Sanitary and Epidemiological Welfare of the Population: Federal Law No. 52-FZ of March 30, 1999]. Konsul'tant Plyus. Available at: http://www.consultant.ru/document/cons_doc_LAW_22481/ (17.12.2017) (in Russian).
} 
event, although each stage is characterized by the specific features.

I. Stage of preparation and construction of the facilities and infrastructure required for an event.

By virtue of the provisions of Part 2, Article 44 of the Federal Law of 30.03.1999 No. 52-FZ "On Sanitary and Epidemiological Welfare of the Population" $^{2}$ in 2007, during the construction, reconstruction, overhaul of capital construction facilities, state sanitary and epidemiological surveillance is in place within the framework of state construction supervision, and also by the bodies authorized to carry out state construction supervision the federal executive authority, executive authorities of the subjects of Russian Federation in accordance with the Russian Federation legislation on urban development. So, the need for laboratory provision of state sanitary and epidemiological surveillance at capital construction sites was practically absent.

The relevance of this problem increased in the preparation for mass international events and a vivid example of this: the preparations for 2014 Winter Olympic Games in Sochi.

Restoration and updating of unused techniques and laboratory equipment required additional financial costs from Rospotrebnadzor institutions, which were almost completely compensated by the Federal Service for Surveillance over Consumer Rights Protection and Human Wellbeing.

Test laboratory centers under jurisdiction of Rospotrebnadzor institutions in the territories of mass international events received the latest laboratory equipment that allows for a wide range of studies of construction and finishing materials. At the stage of preparation for an international event, this equipment was used almost in a round-the-clock mode, and the accumulated potential is advisable to be further used [15].

In Rostov region, in the specified period of time the objects of laboratory control were:

- "Rostov-Arena" stadium under construction;

- training grounds under reconstruction (5 stadiums);

- hotel complexes under construction;

- "Platov" airport complex under construction.

The main objects of research at this stage are the construction, paints and varnishes, both of domestic and foreign manufacturers.

For the expired period of 2017, 356 samples of construction materials were selected by the testing laboratory center of the Federal Budgetary Institution "Center for Hygiene and Epidemiology in Rostov region", and 3445 studies were carried out. Among the determinable indexes: formaldehyde, methanol, toluene, xylene, methyl methacrylate, dibutyl phthalate, dioctyl phthalate, phenol, styrene, ammonia, etc.

A special feature of these studies is the need for consistency in the use of laboratory equipment (climatic chambers, gas chromatographs, etc.). At the same time, the volume of the studied samples of construction materials at the stage of preparation for a mass international event is determined namely by the number of climatic chambers.

Despite the use of the modern highprecision gas chromatographs with a twostage thermal desorber, no samples incompliant with regulatory requirements have been revealed.

In this regard, the issue of laboratory control optimization and determining the scientifically-based indicative parame- 
ters for an integrated safety assessment of construction products becomes topical [3].

In general, the preparatory stage of almost any mass international event is characterized by the benefits of sanitarychemical, sanitary-hygienic and toxicological laboratory studies carried out in stationary conditions in particular, and the absence of certain laboratory equipment used in the intermediate stages of research, significantly reduces the efficiency of using the expensive equipment intended for quantitative evaluation of limiting indices.

\section{Stage of a mass international event itself:}

The most important requirement for laboratory research during an international event is the promptness of the results, which predetermines the use of express methods and direct measurements instruments, i.e. obtaining the result directly at the object of control. In addition, the characteristic feature is the requirements of international organizations to comply with global standards, which are not always harmonized with the national regulations.

For example: for our region, dust is the most common unfavorable factor of atmospheric air pollution. The geographic features of a region play a leading role in this process.

Upon request of international organizations, the assessment of dust level should be carried out taking into account the dispersion of dust, and gas contamination - taking into account the organoleptic properties of certain pollutants.

In order to achieve the set goals, during FIFA World Cup 2018 in Rostov region, the direct-measurement aerosol analyzers with applicators change-over functions for dust differentiation by fractions, and portable chromatographs for identification and qualitative assessment of air pollutants were purchased.
The efficiency of laboratory support at the stage of holding mass international event depends to a large extent on the structured analysis of the available information, incl. the results of sanitary and epidemiological expertise of maximum permissible emissions (MPE), locations of radio-transmitting facilities, maximum permissible discharges, etc. Systematization of expertise sanitary and epidemiological assessments of MPEs allows you to determine the list of emitted substances, taking into account the priority ones in terms of emissions share, and organize a focused laboratory control over the concentration of these pollutants. The use of modern software systems for calculation and evaluation of electromagnetic radiation can define the indicative points for instrumental monitoring of electromagnetic radiation intensity. It should be noted the positive experience with the use of photometers for drinking water express-analysis. Time spent on research, in comparison with the classical photometric and atomic absorption, decreased 2 times, and it became possible to conduct research directly on site.

Among the peculiarities of laboratory control during mass international event, the global organizations requirements for sampling are also worth to pay attention to. For example: the requirement of contact-free temperature determination, the ban on using glass containers in stadiums, etc. In view of this, sterile polymer containers and bags must be used for food products sampling, which does not affect the quality of laboratory tests, but significantly increases their cost.

In general, the mass international event holding stage itself is characterized by an advantage of laboratory research conducted directly on sites, which necessitates the use of express techniques and mobile laboratory equipment. 
III. The post- event stage of laboratory monitoring.

The influence of the already held international event on hygienic factors of habitat requires special attention and is studied incompletely by now. The infrastructure, newly created for a mass international event, has a significant influence on economic situation in the territory of a municipality, and is a catalyst for the processes of changing the structure of the entire region economy.

In the territories hosted mass international events, in the future, there is a tendency to increase tourist flow, which increases the anthropogenic load on a habitat, incl. hotel room stock occupancy, loading on public catering facilities, life support systems, etc. At the same time, calculations of the population consumption needs in the municipalities' territories are primarily focused on the number of inhabitants.

The consequences of the given situation is an increase in the volume of drinking water consumption, an increase in the load on sewage treatment plants, and an increase in the volume of wastewater discharges, a significant increase in the amount of wastes transported to landfill, an increase in traffic, and an increase in fugitive source of emissions, accordingly, etc.

A considerable portion of costs for preparing and operating an infrastructure that affects hygienic factors of the environment during international events is financed from the federal budget, and allows for the planned project operation of all life support systems. At the same time, the operational costs of ensuring proper functioning hygienically critical infrastructure systems of territorial entities after an event are becoming a financial commitment of local budgets, and the occurrence risks of emergency situations are increasing [2].

The peculiarities mentioned should be taken into account at implementing a risk-based model of state sanitary and epidemiological surveillance in the territories that hosted mass international events, so there is a need to revise approaches to laboratory control in these territories.

Conclusions: The laboratory support of state sanitary and epidemiological surveillance in preparing for and hosting mass international events should be arranged taking into account the peculiarities typical for each stage of an event that defines the urgency of developing a hygienic model for laboratory control at mass international events.

Funding. Our research was not granted any sponsors' support.

A conflict of interests. The authors state there is no conflict of interests.

\section{References}

1. Global'nye massovye meropriyatiya: ikh znachenie i vozmozhnosti dlya obespecheniya bezopasnosti zdorov'ya v mire: Doklad VOZ [Global mass events: their significance and possibilities for providing health safety in the world: The WHO report]. 2011, 9 p. Available at: http: //apps.who.int/iris/bitstrem/10665/25910/1/B130-17-ru.rdf(12.01.2018) (in Russian).

2. Onishchenko G.G., Kuz'kin B.P., Rakitin I.A., Bashketova N.S., Korzhaev Yu.N., Grechaninova T.A., Dyatlov I.A., Kutyrev V.V., Toporkov A.V., Karnaukhov I.G., Toporkov V.P., Shcherbakova S.A., Kazakova E.S., Sharova I.N. Obespechenie sanitarno- 
epidemiologicheskogo blagopoluchiya $\mathrm{v}$ period podgotovki i provedeniya sammita «gruppy dvadtsati» v Sankt-Peterburge v 2013 g. Soobshchenie 2. Oorganizatsiya i prioritetnye napravleniya raboty v period provedeniya sammita [Sanitary-Epidemiological Welfare Provision in the Preparations to and Management of the «G-20» Summit in Saint-Petersburg, 2013. Communication 2. Management and Priority Areas of Anti-Epidemic Activities as Regards «G-20» Summit Campaign]. Problemy osobo opasnykh infektsii, 2013, no. 4, pp. 11-15 (in Russian).

3. Cheuvront S.N., Haymes E.M. Thermoregulation and marathon running, biological and environmental influences. Sports. Med., 2001, vol. 31, no. 10, pp. 743-762.

4. Chimenti L., Morici G., Paterno A., Bonanno A., Vultaggio M., [et al.]. Environmental conditions, air pollutants, and airway cells in runners: A longitudinal field study. J. Sports. Sci., 2009, vol. 27, no. 9, pp. 925-993.

5. Rundell K. Effect of air pollution on athlete health and performance. British Journal of Sports. Medicine, 2012, vol. 46, no. 6, pp. 407-412.

6. Lippi G., Guidi G.C., Maffulli N. Air pollution and sports performance in Beijing. Int J. Sports. Med., 2008, vol. 29, pp. 696-698.

7. Bondin V.I. Dvigatel'naya aktivnost' i zdorov'e cheloveka v usloviyakh tekhnogennogo zagryazneniya okruzhayushchei sredy [Physical activity and human health under technogenic contamination of the environment]. Fizicheskaya kul'tura, sport, zdorov'e $i$ dolgoletie: sbornik materialov pyatoi vse rossiiskoi s mezhdunarodnym uchastiem nauchnoi konferentsii. Moscow, 2016, pp. 3-7 (in Russian).

8. Donnelly A.A., T MacIntyre.E., O'Sullivan N., Warrington G., Harrison A.J., Igou E.R., Jones M., Gidlow C., Brick N., Lahart I., Cloak R., Lane A.M. Environmental Influences on Elite Sport Athletes Well Being: From Gold, Silver, and Bronze to Blue Green and Gold. Front Psycho., 2016, vol. 4, no. 7, pp. 1167. DOI: 10.3389/fpsyg.2016.01167

9. Patyashina M.A., Trofimova M.V., Balabanova L.A., Zamalieva M.A. Planirovanie laboratornykh issledovanii ob"ektov okruzhayushchei sredy pri provedenii massovykh meropriyatii [The planning of laboratory tests on environmental settings for conducting mass events]. Meditsina truda $i$ ekologiya cheloveka, 2015, no. 3, pp. 151-155 (in Russian).

10. Romanovich I.K. [et al.]. Obespechenie radiatsionnoi bezopasnosti i protivodeistvie radiatsionnomu terrorizmu pri provedenii massovykh sportivnykh meropriyatii [Provision of radiation safety and fight against radiation terrorism during mass sport events]. In: G.G. Onishchenko, A.Yu. Popova, eds. St. Petersburg, NIIRG im. Prof. P.V. Ramzaeva Publ., 2016, 364 p. (in Russian).

11. Popova A.Yu., Zaitseva N.V., May I.V. Opyt metodicheskoi podderzhki i prakticheskoi realizatsii risk-orientirovannoi modeli sanitarno-epidemiologicheskogo nadzora (2014-2017 gg.) [An experience accumulated in methodical support and practical implementation of risk-oriented model for sanitary-epidemiologic surveillance (2014-2017)]. Aktual'nye voprosy obespecheniya sanitarnoepidemiologicheskogo blagopoluchiya naseleniya na urovne sub"ekta federatsii: Materialy nauchnoprakticheskoi internet-konferentsii. In: A.Yu. Popova, N.V. Zaitseva, eds. Perm', Izdatel'stvo Permskogo natsional'nogo issledovatel'skogo politekhnicheskogo universiteta Publ., 2017, pp. 7-15 (in Russian).

12. Zaitseva N.V., May I.V., Kleyn S.V. Optimizatsiya programm nablyudeniya za kachestvom atmosfernogo vozdukha selitebnykh territorii v sisteme sotsial'no-gigienicheskogo monitoringa na baze prostranstvennogo analiza i otsenki riska dlya zdorov'ya naseleniya [How to optimize monitoring over atmospheric air quality in settlements within social-hygienic monitoring system on the basis of spatial analysis and population health risk assessment]. Permskii meditsinskii zhurnal, 2010, vol. 27, no. 2, pp. 130-138 (in Russian).

13. Zaitseva N.V., May I.V., Kleyn S.V., Vekovshinina S.A., Balashov S.Yu. Prakticheskii opyt otsenki i upravleniya neinfektsionnymi riskami dlya zdorov'ya pri podgotovke 
massovykh sportivnykh meropriyatii (na primere vsemirnoi letnei universiady - $2013 \mathrm{v}$ Kazani i Olimpiiskikh zimnikh igr - 2014 V Sochi) [Practical experience in the assessment and management of non-infectious health risks during the preparation of the mass sports events (using the example of the 2013 summer Universiade in Kazan and the 2014 winter Olympics in Sochi)]. Zdorov'e naseleniya i sreda obitaniya, 2015, vol. 273, no. 12, pp. 4-7 (in Russian).

14. Khairullin A.G., Faizrakhmanova A.R., Karataeva E.S. Negativnaya okruzhayushchaya sreda sportivnykh sooruzhenii [Adverse environment at sport facilities]. Perspektivy nauki - 2015: Sbornik dokladov I Mezhdunarodnogo zaochnogo konkursa nauchnoissledovatel'skikh rabot. Kazan', 2015, pp. 142-145 (in Russian).

15. Anan'ev V.Yu., Sennikova V.G., Garbuzova A.A., Kramarenko A.A. Etapy stanovleniya i perspektivy razvitiya sistemy menedzhmenta kachestva FBUZ «Federal'nyi tsentr gigieny $\mathrm{i}$ epidemiologii» Rospotrebnadzora [Stages of development and prospects for the development of the quality management system Federal Center for Hygiene and Epidemiology of Rospotrebnadzor]. Rossiiskaya gigiena - razvivaya traditsii, ustremlyaemsya v budushchee: Materialy XII Vserossiiskogo s"ezda gigienistov i sanitarnykh vrachei. In: A.Yu. Popova, V.N. Rakitskii, N.V. Shestopalov, eds. Moscow, 2017, vol. 1, pp. 42-43 (in Russian).

Karpushchenko G.V., Motskus A.V. Peculiarities of laboratory support for mass international events. Health Risk Analysis, 2018, no. 2, pp. 105-111. DOI: 10.21668/health.risk/2018.2.12.eng

Received: 28.02 .2018

Accepted: 01.06.2018

Published: 30.06 .2018 